\title{
Land-use history influence the vegetation in coniferous production forests in southern Sweden
}

Per Milberg, Karl-Olof Bergman, Dennis Jonason, Jesper Karlsson and Lars Westerberg

The self-archived postprint version of this journal article is available at Linköping University Institutional Repository (DiVA):

http://urn.kb.se/resolve?urn=urn:nbn:se:liu:diva-156903.

N.B.: When citing this work, cite the original publication.

Milberg, P., Bergman, K., Jonason, D., Karlsson, J., Westerberg, L., (2019), Land-use history influence the vegetation in coniferous production forests in southern Sweden, Forest Ecology and Management, 440, 23-30. https://doi.org/10.1016/j.foreco.2019.03.005

Original publication available at:

https://doi.org/10.1016/j.foreco.2019.03.005

Copyright: Elsevier

http://www.elsevier.com/

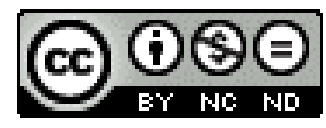




\section{Land-use history influence the vegetation in coniferous production forests in southern Sweden}

\section{Per Milberg*, Karl-Olof Bergman, Dennis Jonason, Jesper Karlsson, Lars Westerberg}

IFM Biology, Conservation Ecology Group, Linköping University, SE58183 Linköping, Sweden

*Correspondence

\section{Abstract}

During the last centuries, land use in Europe intensified, which has led to a drastic decrease in the cover of semi-natural grasslands. In Sweden, much of the lost grasslands was turned into forest. This study investigated if species typical of managed grasslands could be found in coniferous production forests more than 80 years after grassland management ceased. Species and trait composition for plants was investigated in two types of forest differing in land use history (meadow in the 1870s or continuous coniferous forest), and in reference grasslands. The average plant species richness as well as the richness of grassland indicator species were 30\% higher in forests with a history as meadow compared to in forests with a history as forest, hence clear signs of historical grassland management in today's forests. Compared with forests with continuous coniferous history, vegetation in forests with a meadow history tended to be more similar to reference grassland regarding both plant species and especially plant trait composition. The study provides proof of remnant grassland populations in coniferous production as the source for the biodiversity of clearcuts, rather than seed dispersal or seed bank survival. The result highlights the importance of land use for biodiversity of clearcuts, and points to 
the potential value of forests with a history of meadow in grassland conservation and restoration.

\section{Introduction}

It is well-known that species indicative of previous land use can reappear after a disturbance or when management changes (e.g. Vellend et al. 2006, Hermy \& Verheyen 2007, Szabó 2010, Munteanu et al. 2015). Such re-appearances contribute to population persistence and genetics, and they can also be considered as a natural or cultural legacy of the land (Foster et. al 2003, Eriksson \& Cousins 2014). Furthermore, species' re-appearance is a key element of ecological restoration. Two obvious key questions follow regarding reappearances: what is the source for observed recolonisation? And for how long can we expect such recolonization to occur under a land use hostile to the species in question?

A major disturbance affecting a substantial part of forested landscapes is clearcutting, causing drastic changes in vegetation (Bergstedt \& Milberg 2001, Bergstedt et al. 2008, Cesoniene et al. 2018). Evidence is accumulating that reappearance of plants can happen after at least a forest rotation (i.e. 80-120 yrs), i.e. in conjunction with clearcutting (Ibbe et al. 2011, Risberg \& Granström 2012, Jonason et al. 2014). But within the forest/clearcut system, the source for observed recolonisation remains unclear. Jonason et al. (2014) addressed two hypotheses. Firstly, the seed bank hypothesis, i.e. that species with persistent seed bank should be more prevalent on clearcuts with a land use legacy as meadow compared with clearcuts in places with continuous coniferous forest cover. Secondly, the dispersal hypothesis, i.e. species with adaptation for dispersal would be more prevalent on clearcuts with a history of meadow compared with continuous forest cover. Jonason et al. (2014) could find no support for any of these, and conclude that a third hypothesis, that species 
persist as growing specimens through the forestry rotation seemed a more likely explanation (Jonason et al. 2014). Here, we call this the perseverance hypothesis. The fact that plants can survive in conditions that are relatively hostile is a well-known phenomenon (e.g. Eriksson 1996, Bond \& Midgley 2001), and is contributing to situations of "extinction debt" (Helm et al. 2006, Kuusaari et al. 2009), i.e. a time-lag in loss of species in a community. From the point of view of population dynamics, perseverance would mean having a growth rate $(\mathrm{k})$ below 1 .

In the present contribution, we wanted to evaluate the perseverance hypothesis, essential to understand, and exploit, the naturally occurring potential in forestry and ecological restoration. We did this by vegetation inventories in fully mature forests, but with different land use history (forest or meadow in 1870s), destined for clearcut. We also wanted to evaluate if ecological filtering occurred among plant traits during the vegetation change in the chronosequence from open grassland to mature forest. This transition spans more than $100 \mathrm{yrs}$ in our study system and involves elimination of annual mowing or domestic grazing as well as increased shade from trees. Plant traits has proven to be a useful tool to understand plant responses to environmental change (Lavorel \& Garnier 2002), and we expected ecological filtering, i.e. a convergence in traits relevant for the secondary succession from grassland to forests (Kahmen \& Poschlod 2004, Dölle et al. 2008), assessed by shifts in SD of traits. Our hypothesis about ecological filtering predicts that SD of plant traits would be higher in grasslands than in forests with a history as grassland (meadow). The actual changes in trait averages, however, were not of interest to us in the current contribution. We assessed both traits clearly expected to be affected (plant height, grazing/mowing tolerance, Ellenberg light value) and traits less apparently affected: lifeform, Ellenberg moisture, Ellenberg pH, Ellenberg nitrogen and 
seed traits (diaspore mass, terminal velocity of diaspore [maximum speed of falling seed], epizoochory, seed bank).

\section{Material \& methods}

\subsection{Study sites}

The study was performed in southern Sweden in the province of Östergötland (Figure 1), which is in the hemiboreal zone of Scandinavia (Ahti et al. 1968). Forty sites were investigated, 12 semi-natural grasslands and 28 mature forests (which correspond to approximately 80-120 years), planned for clear-cutting within three years. The forests were evenly divided between forests with a management history as meadow or as coniferous forest according to land use maps from 1870s. All forests were coniferous production forests with either Norway spruce (Picea abies) or Scots pine (Pinus sylvestris) as the dominating tree species. The size of the forested areas varied between 2.0 and 7.5 ha, and grasslands between 2.6 and 6.3 ha.

Species-rich semi-natural grasslands were identified using a geographical database managed by the Swedish Board of Agriculture (TUVA database; www.sjv.se/tuva). Such grasslands are generally believed to have a long continuity or management as meadow and/or grazing (e.g. Eriksson et al. 2002, Dahlström et al. 2006, Fredh et al. 2012, Bergstedt et al. 2017).

Forest data were provided by the Swedish Forest Agency to which landowners are obligated to report planned clear-cutting (Skogsdataportalen; http://skogsdataportalen.skogsstyrelsen.se/Skogsdataportalen/). To find suitable forests, historical land-use maps from the 1870s (Häradsekonomiska kartan) were compared with data on forests that were planned for clear-cutting. The old land-use maps contain information about agricultural land, coniferous forests, deciduous forest, meadows, wetlands, roads and more. Although surveyed and 
printed in the $1870 \mathrm{~s}$, part of the information was based on older cadastral maps (Jansson 1993, Runborg 1994). The sampled forests and old meadows did not overlap perfectly and for a forest to be categorized as history as meadow at least $25 \%$ of the area had to be meadow during 1870 ; the whole forest was treated as one unit in the analyses. The reasons for this are (i) the poor micro-spatial accuracy of the old land-use maps, (ii) errors introduced during digitalization e.g. due to rectification, (iii) that borders have shifted, and (iv) that the unit targeted by forestry operations is a forest stand irrespective of previous land use. Furthermore, (v) it is unclear how distinct old land use borders were because even if meadows were always fenced, there were some amount of change by previous meadows falling out of use and new areas taken in. Finally, (vi) grazing is likely to have occurred near meadows which suggest a grazed and relatively open forest near meadows.

Exactly when a former meadow was transformed to production forest is not known. Each area has, however, at least hosted one generation of coniferous forest, which in Östergötland corresponds to approximately 80 years. For the areas with a history as coniferous forest we cannot rule out that they were used as meadow prior to 1870 although we deem it as unlikely since the large-scale transformation from meadow to forest occurred later, during the 20th century (Ihse 1995, Eriksson et al. 2002). To reduce any possible influence of nearby semi-natural grasslands, all forests selected were at least $300 \mathrm{~m}$ from any present-day grassland. To assure that forests selected carried separate populations, the distance between them was also at least $300 \mathrm{~m}$, which is a distance beyond the average dispersal distance for plant species (Thomson et al. 2011). 


\subsection{Plant survey}

The species richness of herbaceous plants was investigated once at each site between early August and late October 2014. Due to phenological variation within the season some species may be underrepresented in the survey (Bergfur et al. 2004), for example species with an early growth peak or senescence of leaves, but this was not expected to bias the result. In each site, one-hundred circular sample plots (radius $1 \mathrm{~m}$ ) were evenly distributed along transects 25 meters apart. Within each sample plot, plants present were recorded and plant frequency was calculated as the number of sample plots in which a species was presence. Plants that could not be identified with certainty to species level, mainly species belonging to the family Poaceae and the genus Carex, were excluded from the data. Melampyrum pratense and M. sylvaticum were difficult to separate in the field and were therefore grouped together.

To classify species as indicators for semi-natural grasslands, the indicator systems of Ekstam \& Forshed (1992) and Bertilsson \& Paltto (2003) were used. Bertilsson and Paltto (2003) is a regional indicator system created to investigate grazing management quality in semi-natural grasslands in the province of Västergötland in southern Sweden. The book by Ekstam and Forshed (1992) does not provide a clear classification of species as indicators for grasslands. The aim of the book is instead to provide a tool for answering questions about grazing, mowing and vegetation development in semi-natural grasslands in Sweden. The book contains tables where species are given several indicator values, for example successional category, light demand, nitrogen demand, species reaction to disturbance by trampling animals and more. To classify species as indicators for semi-natural grasslands, we used the successional category, an indicator that puts species into one of four successional categories (A-D) which is based on when species is lost in an abandoned grassland. (A) concerns species that increase or have a relatively unchanged abundance during 
the first and second year after abandonment but decreases or disappear after three to five years; (B) is species that increase or have a relatively unchanged abundance during the first five years after abandonment but decrease or disappear after ten to fifteen years; (C) Species that increase or have a relatively unchanged abundance during the first fifteen years after abandonment but decrease or disappear after twenty-five to thirty-five years; (D) is species that have their strongest populations in a forested phase in the succession but increase in abundance directly after abandonment. We considered species in (A) and (B) as indicators for semi-natural grasslands. Final classification means a species has been scored as an indicator in at least one of the two indicator systems (Appendix 1).

\subsection{Habitat factors}

At every third plant sample plot, habitat factors were investigated within an area of $100 \mathrm{~m}^{2}$ (circle with radius $5.64 \mathrm{~m}$ ). The species and abundance of living trees and stumps $>10 \mathrm{~cm}$ in diameter were recorded. The size of the living trees was measured at breast height and recorded in diameter classes (10-15 cm, 15-20, $20-25$, etc). These values were converted to basal area per each site. The percent cover of bare rock, residues (from previous thinning or preparing for the clearcut), and exposed mineral soil within the circles were estimated visually. All these factors were investigated to ensure that there was no systematic difference between the two types of forest sites.

\subsection{Plant traits}

To investigate to what extent different plant traits were associated with a certain land-use history, several traits related to dispersal, persistence and habitat requirements were selected for analysis (Eriksson 1996, Fischer \& Stöcklin 1997, Stöcklin \& Fischer 1999, Johansson et al. 2011). A total of 11 traits were chosen for the analysis (Table 2) and data were taken from the LEDA Trait base 
(Kleyer et al. 2008), the Dispersal and Diaspore Database (Hintze et al. 2013) and a database on traits of plants of southern Sweden (Tyler \& Olsson 2013). In these databases, trait values are missing for some species, therefore, all traits could not be assigned to all species. However, at least 65\% (range $65-99 \%$ ) of each trait could be assigned of all species.

\subsection{Statistical analyses}

To investigate if there were any systematic differences between forests with a history as forest or as meadow, mean values and corresponding $95 \%$ confidence intervals were calculated for several habitat factors (Table 1). To describe an individual species' association with forest type, an odds ratio (OR) was calculated (Rita \& Komonen 2008): OR $=(\mathrm{a} / \mathrm{b}) /(\mathrm{c} / \mathrm{d})$, where "a" is the number of plots in continuous coniferous forests with species $i$ occurring and "b" the total number of such plots; "c" is the number of plots in forest with a history as meadow where species $i$ occurs and "d" the total number of such plots. The natural logarithm of the OR and the corresponding 95\% confidence interval was then calculated, $\ln (\mathrm{OR}) \pm 1.96 * \sqrt{ }(1 / \mathrm{a}+1 / \mathrm{b}+1 / \mathrm{c}+1 / \mathrm{d})$. A negative $\ln (\mathrm{OR})$ indicates association with forest with a history as meadow compared to as forest. Only species present in at least two forest sites were included in this analysis (Appendix 2).

To further illustrate the dissimilarities in vegetation composition, data from the two forest types as well as of reference grasslands, were subjected to Principal Component Analysis (PCA, using the CANOCO 5 software: ter Braak \& Šmilauer 2012). These analyses were based on the abundance of 168 plant species at 40 sites (12 grasslands, 28 forests with different history). To investigate if certain plant species traits are associated with a certain site type, trait values per site were calculated as a community-weighted mean (CWM). CWM is the mean trait value of all species present in the community (site) 
weighted by their relative abundances (in our case the frequency of occurrence in the 100 sample plots). Before the CWM was calculated, the species' frequency data were log-transformed in order to reduce the influence of dominating species. The traits used in the analyses consisted of several different variable types; continuous, rank, categorical and binary (Table 2). However, when calculating the CWM all traits were treated as continuous variables.

For each trait, the average value was calculated per forest or grassland. The mean and SD over grasslands, and each of the two forest types were calculated. In addition, corresponding means were calculated weighing each species by its frequency in sample plots. We used the SD and weighted SD to test the hypothesis about ecological filtering.

\section{Results}

In total, 168 herbaceous plant species were found during the survey in forests and grasslands (133 in grasslands; 134 in forest with a history as meadow; 90 in forests with a history as forest) (Appendix 1). Out of these, 48 species were classified as grassland indicator species (46 in Grasslands; 27 in forest with a history as meadow; 19 in forests with a history as forest). The average species richness was $29.6 \%$ higher in forests with a history as meadow compared to in forests with a history as forest (Figure 2a) and the richness of grassland indicator species was on average $30.1 \%$ higher in forests with a history as meadow (Figure 2b).

Most species were more frequent in forests with a history as meadow compared to forests with a history as forest (Figure 3). A total of 107 species were included in species-wise analyses and 53 of them showed distinct association $\left(\mathrm{Cl}_{95 \%}\right.$ did not overlap zero) towards forests with a history as meadow (Figure 3), compared to 14 for forest towards a history as forest. Out of 23 grassland indicator species occurring in the forest plots, 10 showed a distinct preference 
towards forest with a history as meadow and 2 showed preference for forests with a history as forest.

Land use history affected both the species (Figure 4) and trait composition (Figure 5) in forests. A meadow-history of forests showed a tendency to be more similar to grasslands regarding both species (Figure 4) and trait composition (Figure 5) compared to areas with a forest history. When analysing community-weighted traits, grasslands were distinctly different from forests mainly in Ellenberg light, Grazing tolerance and Seed bank persistence (Figure 5a). In contrast, only one trait was larger in coniferous forest continuum: terminal velocity (Figure 5a).

Our hypothesis that ecological filtering, executed by reduced grazing and/or light, is important when turning from grassland to forest, predicts that SD of plant traits would be higher in grasslands than in forests with a history as grassland (meadow). There were, however, no significant differences in the SD, nor the weighted SD, for any of the 11 traits evaluated (Table 3 ). In two cases there was a tendency for a difference, but both involved grasslands having the lower SD, contrary to the hypothesis.

\section{Discussion}

\subsection{Land use legacy and perseverance}

The results of this study clearly demonstrated that land use history can influence present-day plant species and trait composition in hemiboreal forests of Sweden with total species richness and richness of grassland indicator species being higher, on average, in forests with a history as meadow compared to in forests with a history as forest. Other studies have also shown that historical land use affect present day flora, for example in agricultural landscapes (Gustavsson et al. 2007) and clear-cuts (Jonason et al. 2014, 2016). Effects have also been 
shown for other organisms such as butterflies (Ibbe et al. 2011, Blixt et al. 2015), also one study showed that watershed land use in the 1950 affected present day diversity of stream invertebrates and fishes (Harding et al. 1998). Historical land use can also affect the structure and function of whole ecosystems and it has been shown to be important in different biomes and habitats (Foster et al. 2003). The effects of land use can last for centuries (Dahlström et al. 2006, Fortuny et al. 2014) or in some cases even for millennia, as studies have shown that the farming intensity during the period AD 50-250 influenced species richness and plant composition today (Dupouey et al. 2002). The current study showed that remnant population of typical grassland species survive at least 80 years after that grassland management has changed to coniferous production forest. As mentioned above, Jonason et al. (2014) proposed three hypotheses for the source of these grassland species' occurrence on clearcuts: seed bank in soil, dispersal from nearby grasslands or perseverance in the shade of forest. They could find no support of the first two, while the present study provided clear support for the perseverance hypothesis, i.e. populations of grassland species persist in the shade of coniferous forest as remnant populations (Eriksson 1996, Dahlström et al. 2006). Hence, certain grassland species can persist in a changed habitat following the transitions of land use (meadow to forest to clear-cut) that occurred in southern Sweden during the last century. Or put another way, grassland species in forest that used to be grassland are subject to extinction debt (Kuussaari et al. 2009) but instalments are few and spaced in time.

Even if there is strong support for the perseverance hypothesis, this does not rule out that seed dispersal and/or seed bank may play some role too. For example, seed dispersal within a forest might help population survival by redistributing seeds from sun-light areas like verges or glades to darker areas. 
Furthermore, seed bank survival might help boost population growth after a clear cut.

\subsection{Traits}

During the transition from grassland to dense coniferous forest, drastic changes occur in response to reduced light and reduced grazing. This was clearly reflected in the community-weighted trait estimates for Ellenberg light and grazing tolerance, that both decreased. Grazing is an obvious factor that maintains grassland richness and composition (Dupré \& Diekmann 2001, Öckinger et al. 2006, Milberg et al. 2017) and it is well-established that shading is detrimental to many grassland species (Einarsson \& Milberg 1999, Skornik et al. 2008). Therefore, we had assumed that ecological filtering would reduce the variation in Ellenberg light value due to increased shading during the succession from grassland to mature forest, i.e. that the standard deviation (SD) of this trait would be smaller in forest. At the same time, the elimination of grazing would increase variation in plant height and grazing/mowing tolerance. We found no support for these assumptions in our data, nor for change in SD in the other traits evaluated. It remains open to speculation whether this is due to design weakness (space-for-time design), or to a faulty hypothesis.

\subsection{Implications for conservation and restoration}

The presence of grassland plant species in forest, as a legacy of earlier land use, indicate a conservation potential. Some of these plants have become rare today and are in need of an increase in suitable habitat to ensure long-term survival (Nilsson et al. 2013, Hoekstra et al. 2005). Studies have shown that restoration management by grazing after clear-cutting on sites with grassland history have a positive effect on the grassland flora (Piqueray et al. 2015) and that grassland restoration is possible decades after abandonment (Skórka 2007). Therefore, there is a potential for grassland restoration in forests with meadow history by 
introducing grazing or mowing after clearcut (Van Uytvanck \& Verheyen 2014). Old land use information may also be valuable when selecting sites for restauration or creation of woodland pastures (Roellig et al. 2016).

Remnant grassland species that flourish after a clearcut can provide nectar and other resources for species that we normally associate with grasslands (Viljur \& Teder 2018, Ohwaki et al. 2018, Bergman et al. 2018). A practical issue is then how targeted populations of plants can be boosted. This can be done by postponing reforestation, which should give remnant populations more time to expand on the area and give new species confined to open areas a chance to establish. To maintain favourable conditions for grassland species during afforestation, some parts of the forests could be kept open and secondary succession allowed to proceed in the absence of planted trees. It is also likely that planting deciduous trees will prolong the time period that clearcuts are favourable for grassland species.

Studies have shown that plant species richness is higher in semi-natural grasslands (Söderström et al. 2001, Öckinger et al. 2012), road verges, midfield islets (Lindborg et al. 2014) and grasslands on former arable fields (Cousins \& Aggemyr 2008) in forested landscapes compared to agricultural landscapes. This "supportive" influence of forests suggests that grassland populations might not be as fragmented as generally thought.

The current study points to the potential for conservation of grassland species in forests with history as meadow, either by restoration, modified re-forestation methods, or retention forestry with focus on the grassland species. With proper management there is potential to strengthen typical grassland populations in the landscape, both by increasing the chance of remnant populations surviving and by enhancing the connectivity of suitable habitats for the species in the landscape. 


\subsection{Conclusions}

This study shows that grassland species might be more common in the landscape than assumed due to remnant grassland populations in coniferous production forests with a history of grassland management. Furthermore, this study highlights the use of such forests in grassland conservation and restoration. Restoration by grazing animals after clear-cutting has been shown to be successful and favour a lot of grassland plant species (Piqueray et al. 2015). Conservation aims can also be achieved by postponing afforestation, mowing or grazing a time after harvest and planting deciduous trees instead of coniferous.

\section{Acknowledgement}

We thank Malin Tälle for help during field work and Boxholms Skogar AB and private forest owners for allowing us to conduct fieldwork on their land. The Swedish Forest Society provided financial support.

\section{References}

Ahti T, Hämet-Ahti L, Jalas J (1968) Vegetation zones and their sections in northwestern Europe. Annales Botanici Fennici 5, 169-211

Bergfur J, Carlsson A, Milberg P (2004) Phenological changes within a growth season in two semi-natural pastures in southern Sweden. Annales Botanici Fennici 41, 15-25

Bergman K-O, Dániel Ferreira J, Milberg P, Öckinger E, Westerberg L (2018) Landscape mediated patterns of butterfly occurrence in semi-natural grasslands. Landscape Ecology 
Bergstedt J, Milberg P (2001) The impact of logging intensity on field-layer vegetation in Swedish boreal forests. Forest Ecology \& Management 154, 105115

Bergstedt J, Hagner M, Milberg P (2008) Effects on vegetation composition of a modified forest harvesting and propagation method compared with clearcutting, scarification and planting. Applied Vegetation Science 11, 159-168

Bergstedt J, Axelsson A-L, Karlsson J, Lönander J, Törnqvist L, Milberg P (2017) Förändringar i Eklandskapet 1927 till 2013: i den första

Riksskogstaxeringens fotspår. Svensk Botanisk Tidskrift 111, 331-343 (in Swedish)

Bertilsson A, Paltto H (2003) Hagar i skaraborg år 2001: en återinventering med miljöövervakningssyfte. County Administration Board of Västra Götaland, 2003:15. (In Swedish)

http://www.lansstyrelsen.se/vastragotaland/SiteCollectionDocuments/Sv/publik ationer/2003/rapport200315.pdf. Accessed 24 November 2014

Blixt T, Bergman K-O, Milberg P, Westerberg L, Jonason D (2015) Clear-cuts in production forests are not matrix, but neo-habitats for butterflies. Acta Oecologica 69, 71-77

Bond WJ, Midgley JJ (2001) Ecology of sprouting in woody plants: the persistence niche. Trends in Ecology \& Evolution 16, 45-51

Cesoniene L, Daubaras R, Kaskonas P, Kaskoniene V, Maruska AS, Tiso N, Zych M (2018) Initial impact of clear-cut logging on dynamics of understory vascular plants and pollinators in Scots pine-dominated forests in Lithuania. Turkish Journal of Agriculture \& Forestry 42, in press doi:10.3906/tar-1804-71 
Cousins SA, Aggemyr E (2008) The influence of field shape, area and surrounding landscape on plant species richness in grazed ex-fields. Biological Conservation 141, 126-135

Dahlström A, Cousins SAO, Eriksson O (2006) The History (1620-2003) of Land Use, People and Livestock, and the Relationship to Present Plant Species Diversity in a Rural Landscape in Sweden. Environment \& History 12, 191-212

Dölle M, Bernhardt-Römermann M, Parth A, Schmidt W (2008) Changes in life history trait composition during undisturbed old-field succession. Flora 203, $508-522$

Dupouey JL, Dambrine E, Laffite JD, Moares C (2002) Irreversible impact of past land use on forest soils and biodiversity. Ecology 83, 2978-2984

Dupré, C., \& Diekmann, M. (2001). Differences in species richness and lifehistory traits between grazed and abandoned grasslands in southern Sweden. Ecography 24, 275-286

Einarsson A, Milberg P (1999) Species richness and distribution in relation to light in wooded meadows and pastures in southern Sweden. Annales Botanici Fennici 36, 99-107

Ekstam U, Forshed N (1992) Om hävden upphör: Kärlväxter som indikatorarter i ängs- och hagmarker (If grassland management ceases; Vascular plants as indicators species in meadows and pastures.). Naturvårdsverket Förlag, Solna, Sweden. (In Swedish with English summary)

Eriksson O (1996) Regional dynamics of plants: a review of evidence for remnant, source-sink and metapopulations. Oikos 77, 248-258

Eriksson O, Cousins SA (2014) Historical landscape perspectives on grasslands in Sweden and the Baltic region. Land 3, 300-321 
Eriksson O, Cousins S, Bruun HH (2002) Land-use history and fragmentation of traditionally managed grasslands in Scandinavia. Journal of Vegetation Science 13, 743-748

Eriksson O, Cousins SAO, Bruun HH (2002) Land-use history and fragmentation of traditionally managed grasslands in Scandinavia. Journal of Vegetation Science 13, 743-748

Fischer M, Stöcklin J (1997) Local Extinctions of Plants in Remnants of Extensively Used Calcareous Grasslands 1950-1985. Conservation Biology 11, 727-737

Fortuny X, Carcaillet C, Chauchard S (2014) Land use legacies and site variables control the understorey plant communities in Mediterranean broadleaved forests. Agriculture, Ecosystems \& Environment 189, 53-59

Foster D, Swanson F, Aber J, Burke I, Brokaw N, Tilman D, Knapp A (2003) The importance of land-use legacies to ecology and conservation. BioScience $53,77-88$

Fredh D, Broström A, Zillén L, Mazier F, Rundgren M, Lagerås P (2012) Floristic diversity in the transition from traditional to modern land-use in southern Sweden a.d. 1800-2008. Vegetation History \& Archaeobotany 21, $439-452$

Gustavsson E, Lennartsson T, Emanuelsson M (2007) Land use more than 200 years ago explains current grassland plant diversity in a Swedish agricultural landscape. Biological Conservation 138, 47-59

Harding JS, Benfield EF, Bolstad PV, Helfman GS, Jones EBD (1998) Stream biodiversity: the ghost of land use past. Proceedings of the National Academy of Sciences of the USA 95, 14843-14847 
Helm A, Hanski I, Pärtel M (2006) Slow response of plant species richness to habitat loss and fragmentation. Ecology Letters 9, 72-77

Hermy M, Verheyen K (2007) Legacies of the past in the present-day forest biodiversity: a review of past land-use effects on forest plant species composition and diversity. Ecological Research 22, 361-371

Hintze C, Heydel F, Hoppe C, Cunze S, Konig A, Tackenberg O (2013) D-3: The Dispersal and Diaspore Database - Baseline data and statistics on seed dispersal. Perspectives in Plant Ecology, Evolution \& Systematics 15, 180-192

Hoekstra J, Boucher T, Ricketts T, Roberts C (2005) Confronting a biome crisis: Global disparities of habitat loss and protection. Ecology Letters 8, 23-29

Ibbe M, Milberg P, Tunér A, Bergman K (2011) History matters: Impact of historical land use on butterfly diversity in clear-cuts in a boreal landscape. Forest Ecology \& Management 261, 1885-1891

Ihse M (1995) Swedish agricultural landscapes - patterns and changes during the last 50 years, studied by aerial photos. Landscape \& Urban Planning 31, 21 37

Jansson U (1993) Ekonomiska kartor 1800-1934. Riksantikvarieämbetet. Almqvist \& Wiksell Tryckeri, Uppsala. 76 p

Johansson VA, Cousins SA, Eriksson O (2011) Remnant populations and plant functional traits in abandoned semi-natural grasslands. Folia Geobotanica 46, 165-179

Jonason D, Ibbe M, Milberg P, Tunér A, Westerberg L, Bergman KO (2014) Vegetation in clear-cuts depends on previous land use: a century-old grassland legacy. Ecology \& Evolution 4, 4287-4295 
Jonason D, Bergman K-O, Westerberg L, Milberg P (2016) Land-use history exerts long-term effects on the flora in clear-cuts. Applied Vegetation Science $19,634-643$

Kahmen S, Poschlod P (2004) Plant functional trait responses to grassland succession over 25 years. Journal of Vegetation Science 15, 21-32

Kleyer M, Bekker RM, Knevell IC, Bakker JP, Thompson K, Sonnenschein M, Poschlod P, van Groenendae JM, Klimes L, Klimesová J, Klotz S, Rusch GM, Hermy M, Adriaens D, Boedeltje G, Bossuyt B, Dannemann A, Endels P, Götzenberger L, Hodgson JG, Jacke AK, Kühn I, Kunzmann D, Ozinga WA, Römermann C, Stadler M, Schlegelmilch J, Steendam HJ, Tackenberg O, Wilmann B, Cornelissen JHC, Eriksson O, Garnier E, Peco B (2008). The LEDA Traitbase: a database of life-history traits of the northwest European flora. Journal of Ecology 96, 1266-1274

Kuussaari M, Bommarco R, Heikkinen RK, Helm A, Krauss J, Lindborg R, et al. (2009) Extinction debt: a challenge for biodiversity conservation. Trends in Ecology \& Evolution 24, 564-571

Lavorel S, Garnier E (2002) Predicting changes in community composition and ecosystem functioning from plant traits: revisiting the Holy Grail. Functional Ecology 16, 545-556

Lindborg R, Plue J, Andersson K, Cousins SA (2014) Function of small habitat elements for enhancing plant diversity in different agricultural landscapes. Biological Conservation 169, 206-213

Milberg P, Tälle M, Fogelfors H, Westerberg L (2017) The biodiversity cost of reducing management intensity in species-rich grasslands: Mowing annually vs. every third year. Basic \& Applied Ecology 22, 61-74 
Munteanu C, Kuemmerle T, Keuler NS, Müller D, Balázs P, Dobosz M, Griffiths P, Halada L, Kaim D, Király G, Konkoly-Gyuró É, Kozak J, Lieskovskyf J, Ostafin K, Ostapowicza K, Shandra O, Radeloff VC (2015) Legacies of 19th century land use shape contemporary forest cover. Global Environmental Change 34, 83-94

Nilsson S, Franzén M, Pettersson L (2013) Land-use changes, farm management and the decline of butterflies associated with semi-natural grasslands in southern Sweden. Nature Conservation 6, 31-48

Öckinger E, Eriksson A, Smith H (2006) Effects of grassland abandonment, restoration and management on butterflies and vascular plants. Biological Conservation 133, 291-300

Öckinger E, Lindborg R, Sjödin NE, Bommarco R (2012) Landscape matrix modifies richness of plants and insects in grassland fragments. Ecography 35, 259-267

Ohwaki A, Koyanagi TF, Maeda S (2018) Evaluating forest clear-cuts as alternative grassland habitats for plants and butterflies. Forest Ecology \& Management 430, 337-345

Piqueray J, Ferroni L, Delescaille LM, Speranza M, Mahy G, Poschlod P (2015). Response of plant functional traits during the restoration of calcareous grasslands from forest stands. Ecological Indicators 48, 408-416

Rita H, Komonen A (2008) Odds ratio: an ecologically sound tool to compare proportions. Annales Zoologici Fennici 45, 66-72

Roellig M, Sutcliffe LM, Sammul M, von Wehrden H, Newig J, Fischer J (2016) Reviving wood-pastures for biodiversity and people: A case study from western Estonia. Ambio 45, 185-195 
Risberg L, Granström A (2012) Seed dynamics of two fire-dependent Geranium species in the boreal forest of southeastern Sweden. Botany 90, 794805Runborg S (1994) Historiska kartor: underlag för natur- och kulturmiljövård i skogen. Skogsstyrelsen, Rapport 1994:5, 42 p.

Skórka P, Settele J, Woyciechowski M (2007) Effects of management cessation on grassland butterflies in southern Poland. Agriculture, Ecosystems \& Environment 121, 319-324

Szabó P (2010) Why history matters in ecology: an interdisciplinary perspective. Environmental Conservation 37, 380-387

Škornik S, Šajna N, Kramberger B, Kaligarič S, Kaligarič M (2008) Last remnants of riparian wooded meadows along the middle Drava River (Slovenia): species composition is a response to light conditions and management. Folia Geobotanica 43, 431-445

Söderström BO, Svensson B, Vessby K, Glimskär A (2001) Plants, insects and birds in semi-natural pastures in relation to local habitat and landscape factors. Biodiversity \& Conservation 10, 1839-1863

Stöcklin J, Fischer M (1999) Plants with longer-lived seeds have lower local extinction rates in grassland remnants 1950-1985. Oecologia 120, 539-543 ter Braak CJF, Šmilauer P (2012) Canoco reference manual and user's guide: software for ordination, version 5.0. Microcomputer power.

Thomson FJ, Moles AT, Auld TD, Kingsford RT (2011) Seed dispersal distance is more strongly correlated with plant height than with seed mass. Journal of Ecology 99, 1299-1307

Tyler T, Olsson O (2013) Fördjupad analys av Skånes Flora-2. Indikatorvärden. Botaniska Notiser 146, 17-24 
Van Uytvanck J, Verheyen K (2014) Grazing as a tool for wood-pasture restoration and management. In: Hartel T, Plieninger T (eds). European woodpastures in transition: A social-ecological approach. Routledge. Oxon/New York, pp 149-167

Vellend M, Verheyen K, Jacquemyn H, Kolb A, Van Calster H, Peterken G, Hermy M (2006) Extinction debt of forest plants persists for more than a century following habitat fragmentation. Ecology 87, 542-548

Viljur ML, Teder T (2018) Disperse or die: Colonisation of transient open habitats in production forests is only weakly dispersal-limited in butterflies. Biological Conservation 218, 32-40 


\section{Figure legends}

Figure 1. Map over Sweden (left) and the study area in the southern part of the province Östergötland (right).

Figure 2. Average plant species richness, with $\mathrm{Cl}_{95 \%}$, of forests with a history as forest $(n=14)$ and as meadow $(n=14)$ in the 1800 s for (a) all species combined and for (b) species classified as grassland indicator species. The reference grassland sites had on average 74.2 species $\left(\mathrm{CI}_{95 \%} 68.6 ; 79.9\right)$ and 27.4 grassland indicator species $(25.2 ; 29.6)$.

Figure 3. Odds ratio (natural logarithm) with $\mathrm{CI}_{95 \%}$ (whiskers) for species in forests differing in land use history. Positive values of a species indicate preference towards forests with history as forest and negative values indicates a preference towards forest with history as meadow. Size of the black symbol is proportional to the total frequency of a species. Species labelled with "*” are grassland indicator species.

Figure 4. PCA of species composition data from forest with different land use history (meadow or coniferous forest in the 1870s) and reference grasslands (12). Eigenvalues of PC1 and PC2 were 51.2 and 9.2\%, respectively. Arrows indicate species.

Figure 5. PCA of community-weighted trait data from forest with different land use history (meadows or coniferous forest in the 1870s) and reference grasslands. Eigenvalues of PC1 and PC2 were 50.3 and 31.4\%, respectively. 


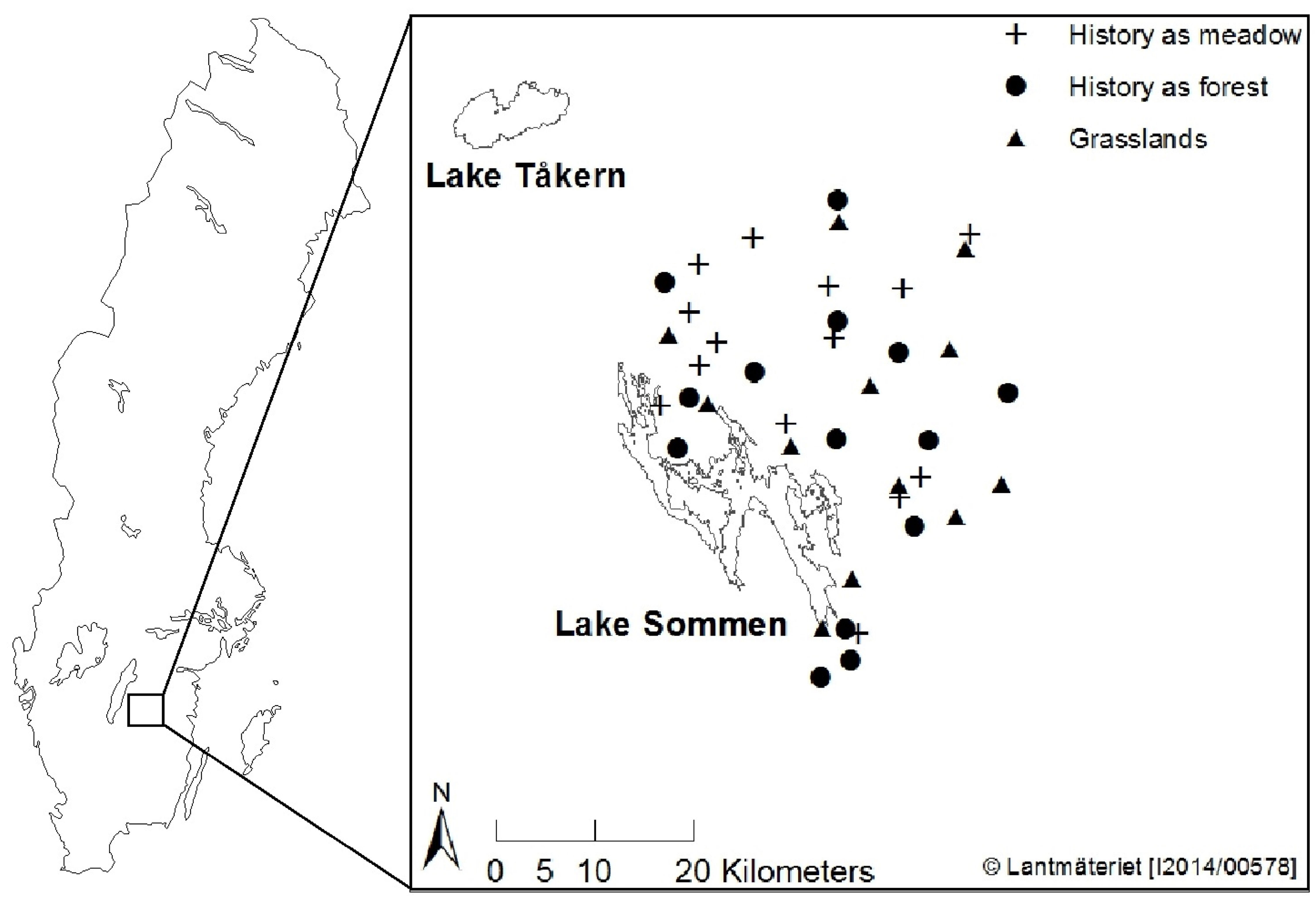




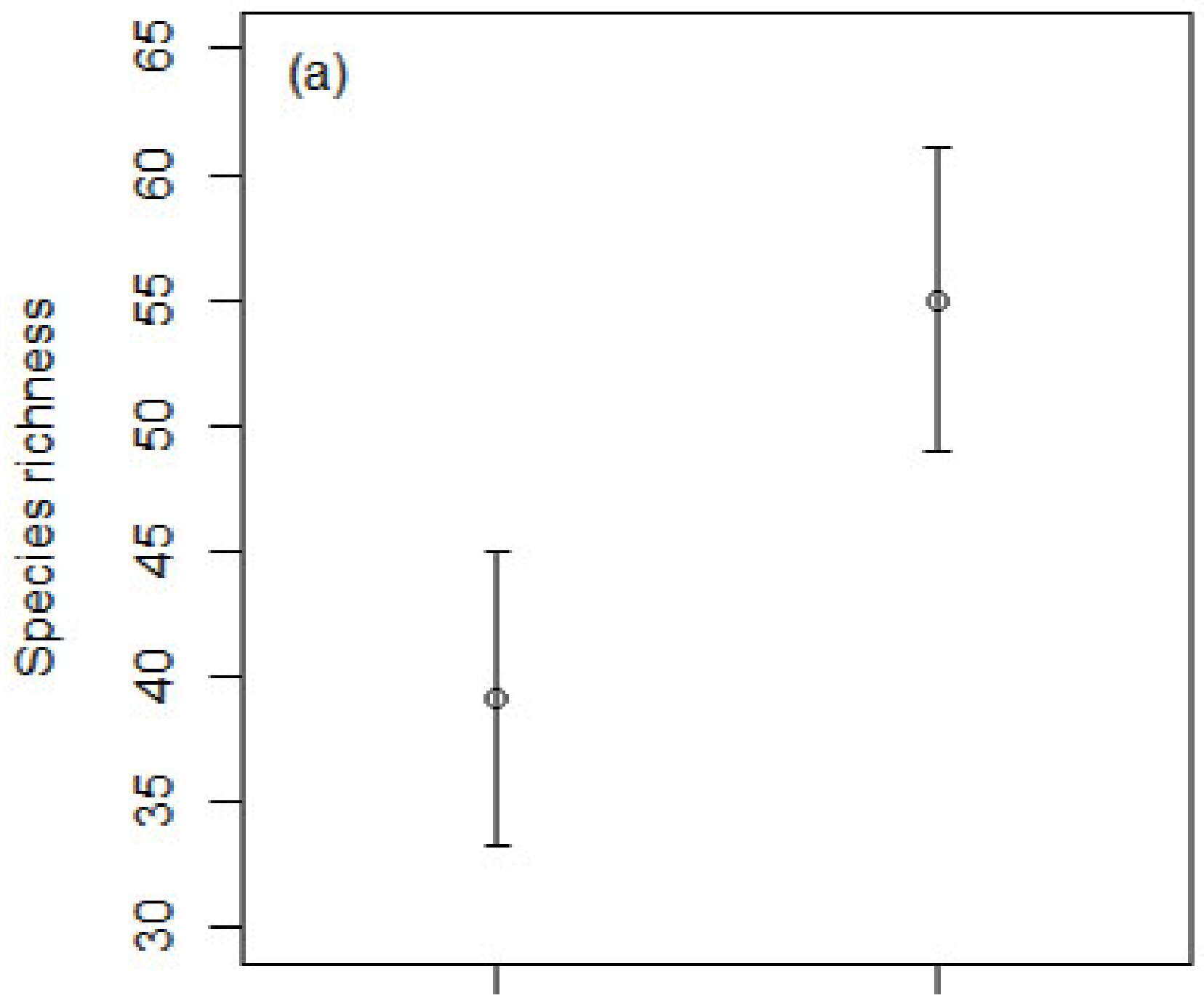

History as forest History as meadow 


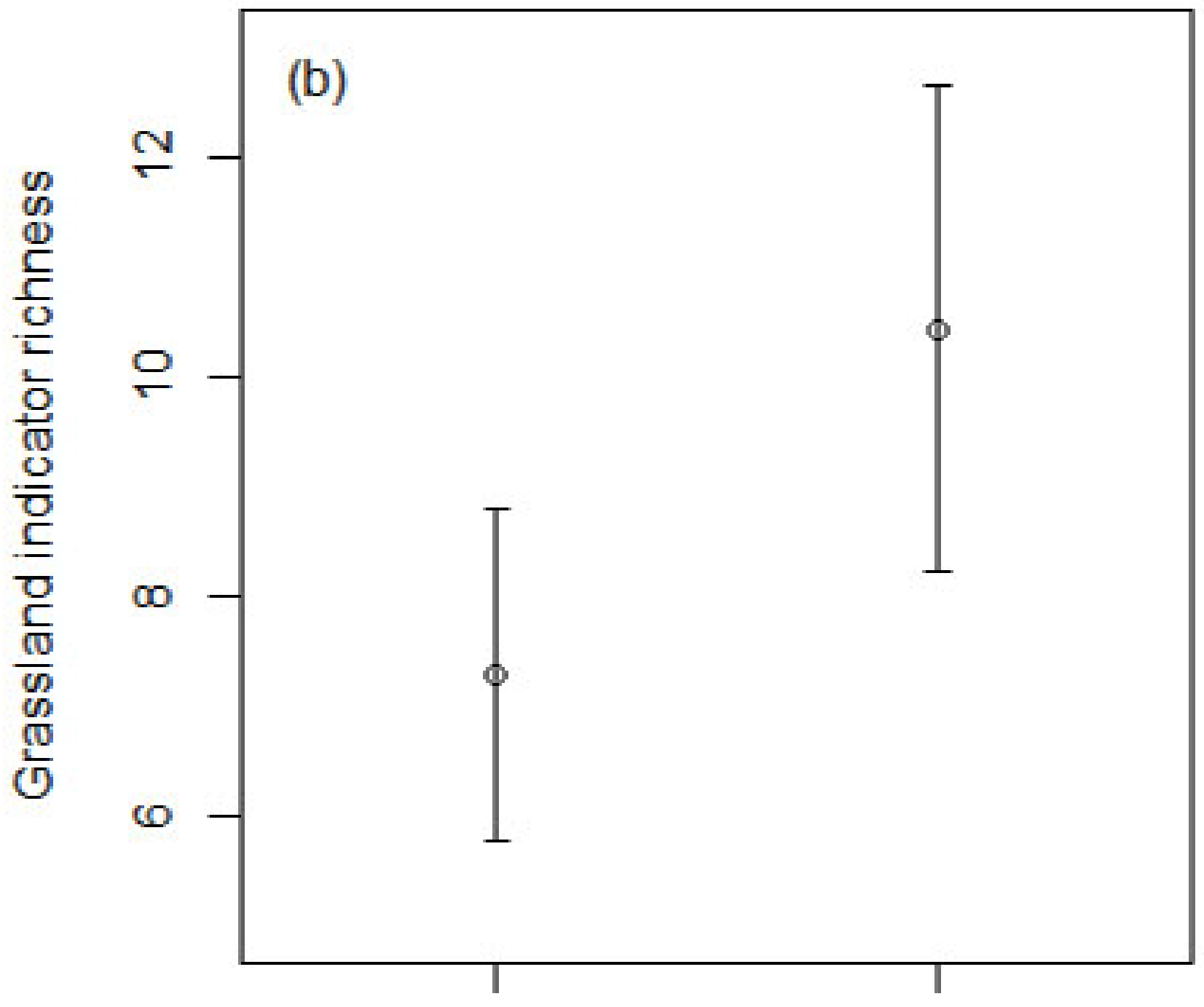

History as forest History as meadow 
Equisetum pratense

Geranium robertianum

Rhododendron tomentosum

Vaccinium uliginosum

Tussilago farfara

Galeopsis tetrahit

Stachys sylvatica

Cirsium arvense

Poa nemoralis

Phragmites australis

Urtica dioica

Geum rivale

Ranunculus repens

Epilobium adenocaulon

*Alchemilla vulgaris

Glechoma hederacea

Senecio sylvaticus

Anthriscus sylvestris

*Pilosella lactucella

Juncus effusus

Aegopodium podagraria

*Leucanthemum vulgare

Cirsium palustre

Phleum pratense

Rumex acetosa

*Scorzonera humilis

${ }^{*}$ Ranunculus acris

*Trollius europaeus

Deschampsia cespitosa

Astragalus glycyphyllos

Juncuscon glomeratus

Prunella vulgaris

Pyrola rotundifolia

Taraxacum sect.Ruderalia

Daphne mezereum

Anemone nemorosa

${ }^{\star}$ Filipendula ulmaria

Gnaphalium sylvaticum

Paris quadrifolia

Equisetum arvense

*Trifolium pratense

Rubus saxatilis

Vicia cracca

Lathyrus pratensis

Chamerion angustifolium

*Pilosella officinarum

*Veronica chamaedrys

${ }^{*}$ Campanula rotundifolia

*Primula veris

Lactuca muralis

Dryopteris filix-mas

Clinopodium vulgare

Empetrum nigrum

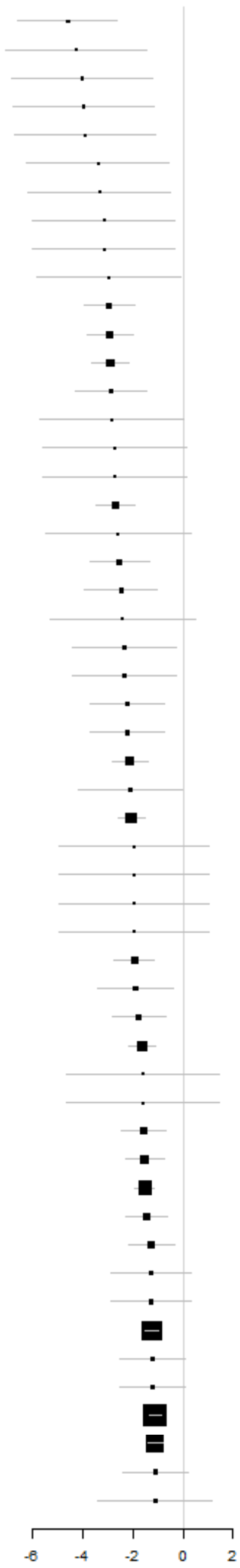


Anemone hepatica

*Ajuga pyramidalis

Trifolium medium

*Pimpinella saxifraga

*Hypericum maculatum

Agrostis capillaris

Hylotelephium telephium

Equisetum sylvaticum

Dactyils glomerata

Stellaria media

Achillea millefolium

Solidago virgauera

Convallaria majalis

Vicia sylvatica

Hieracium sect.Hieracium

Knautia arvensis

Geranium sylvaticum

${ }^{*}$ Campanula persicifolia

Rubus idaeus

Phegopteris connectilis

Potentilla erecta

Vicia sepium

Fragaria vesca

Viola riviniana

Chrysosplenium alternifolium

*Succisa pratensis

*Lathyrus linifolius

*Veronica officinalis

Lycopodium annotinum

Lysimachia vulgaris

Calamagrostis arundinacea

Melampyrum pratense/sylvaticum

Polypodium vulgare

Maianthemum bifolium

Orthilia secunda

Oxalis acetosella

Potentilla palustris

Luzula pilosa

Trientalis europaea

Mentha arvensis

*Lotus corniculatus

*Festuca ovina

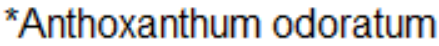

Calluna vulgaris

Vaccinium vitis-idaea

Pteridium aquilinum

Deschampsia flexuosa

Vaccinium myrtillus

Gymnocarpium dryopteris

${ }^{*}$ Rumex acetosella

Scutellaria galericulata

Monotropa hypopitys

Linaea borealis

Goodyera repens

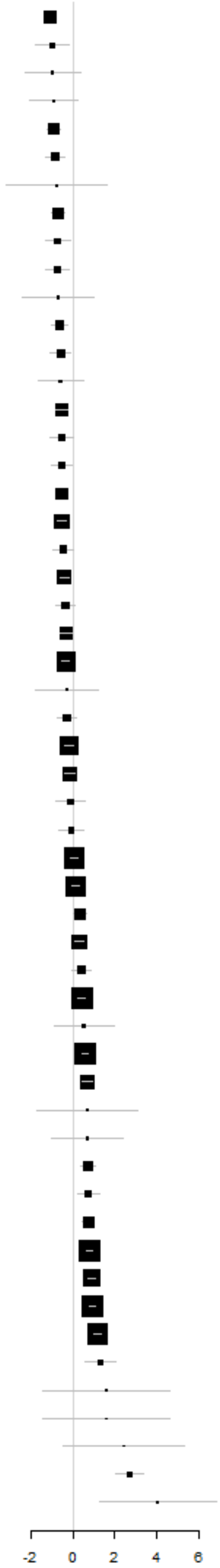




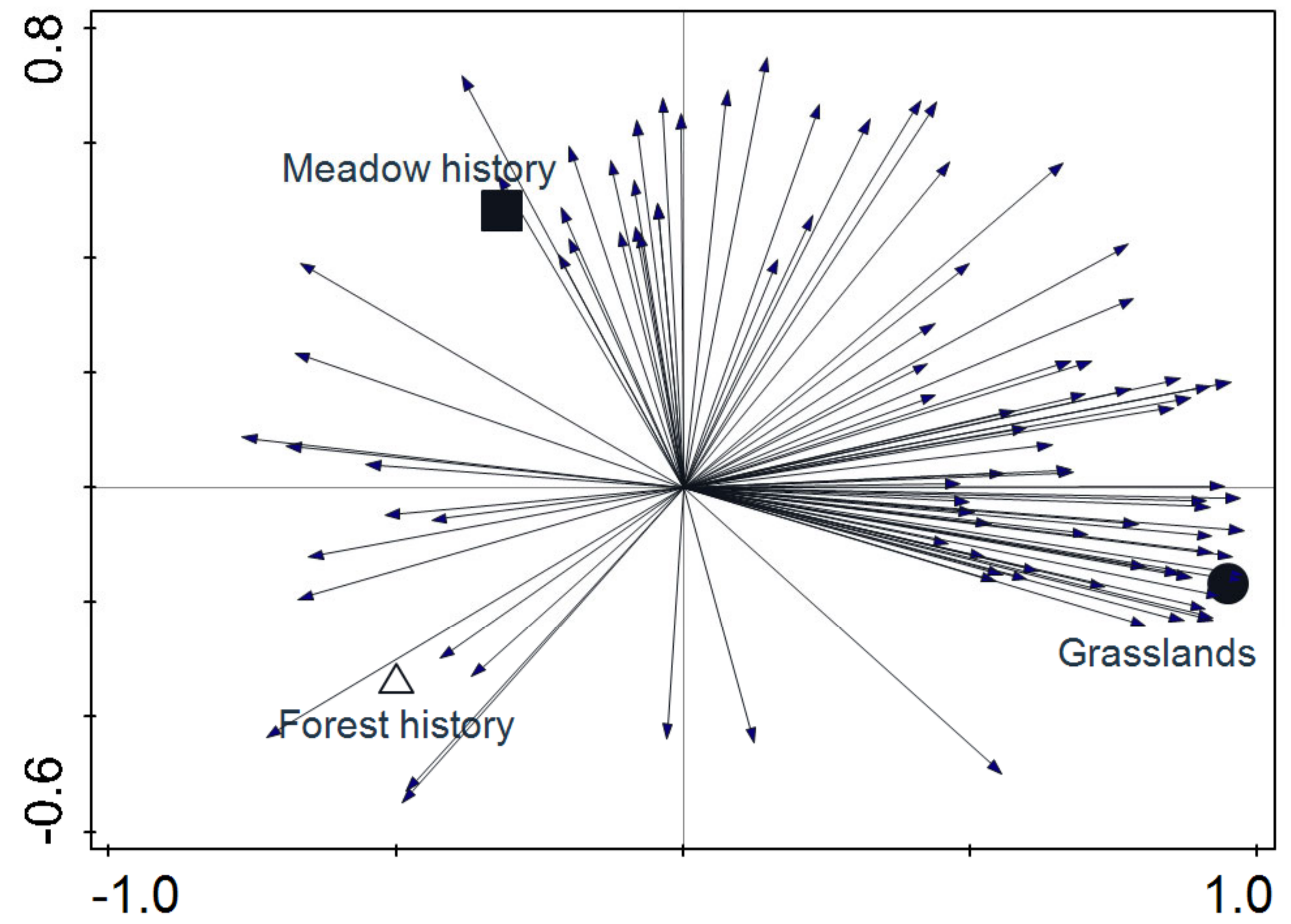




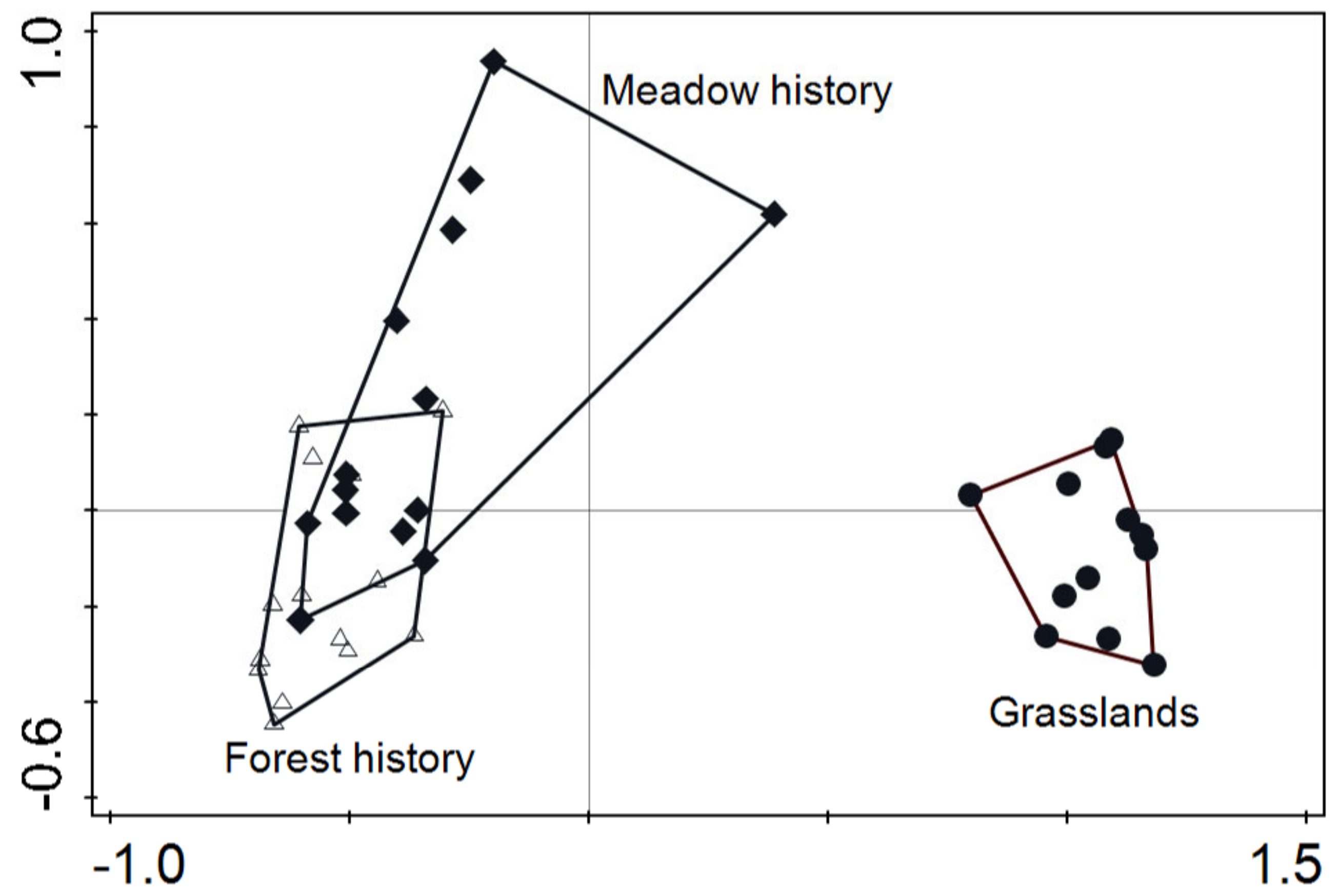




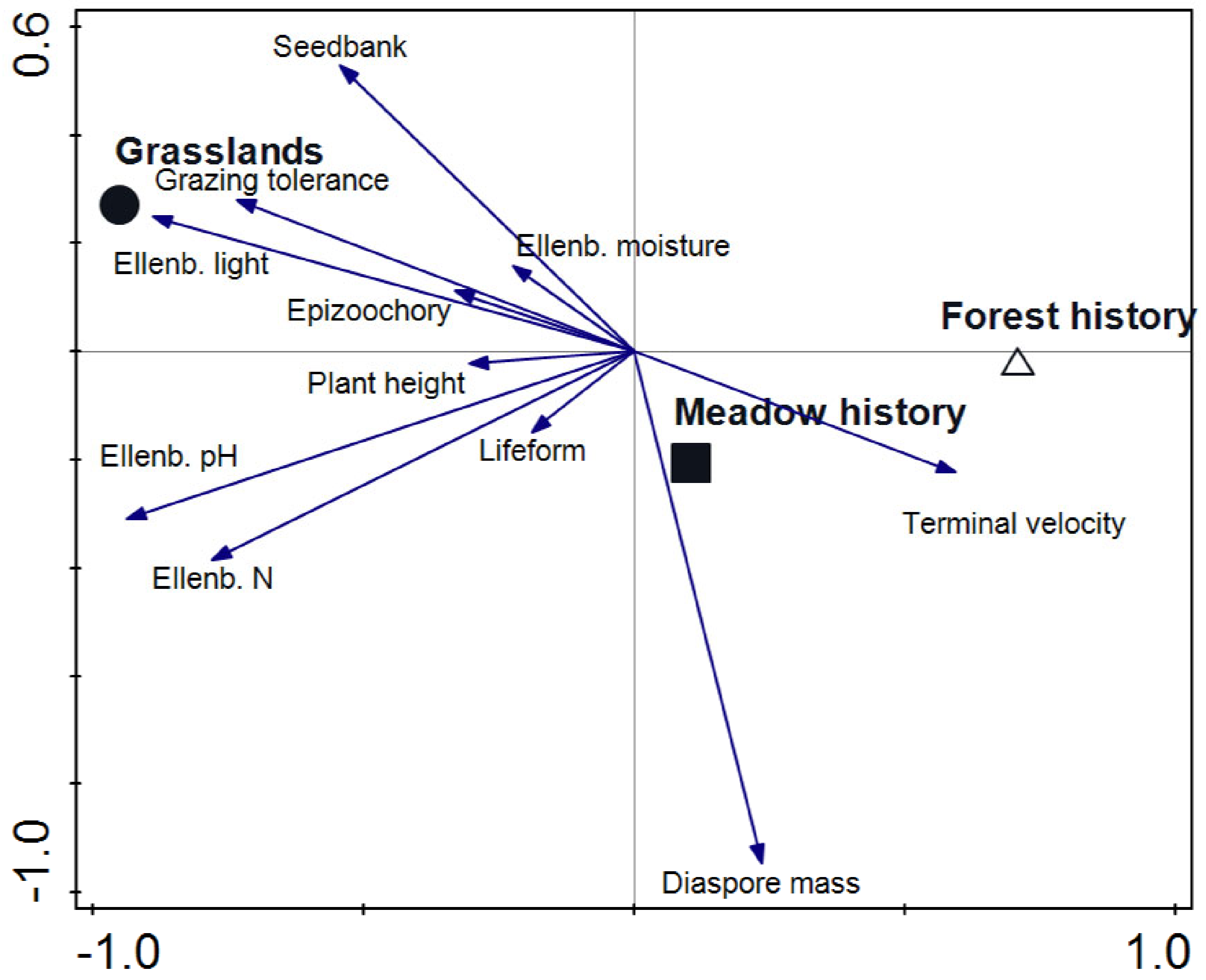




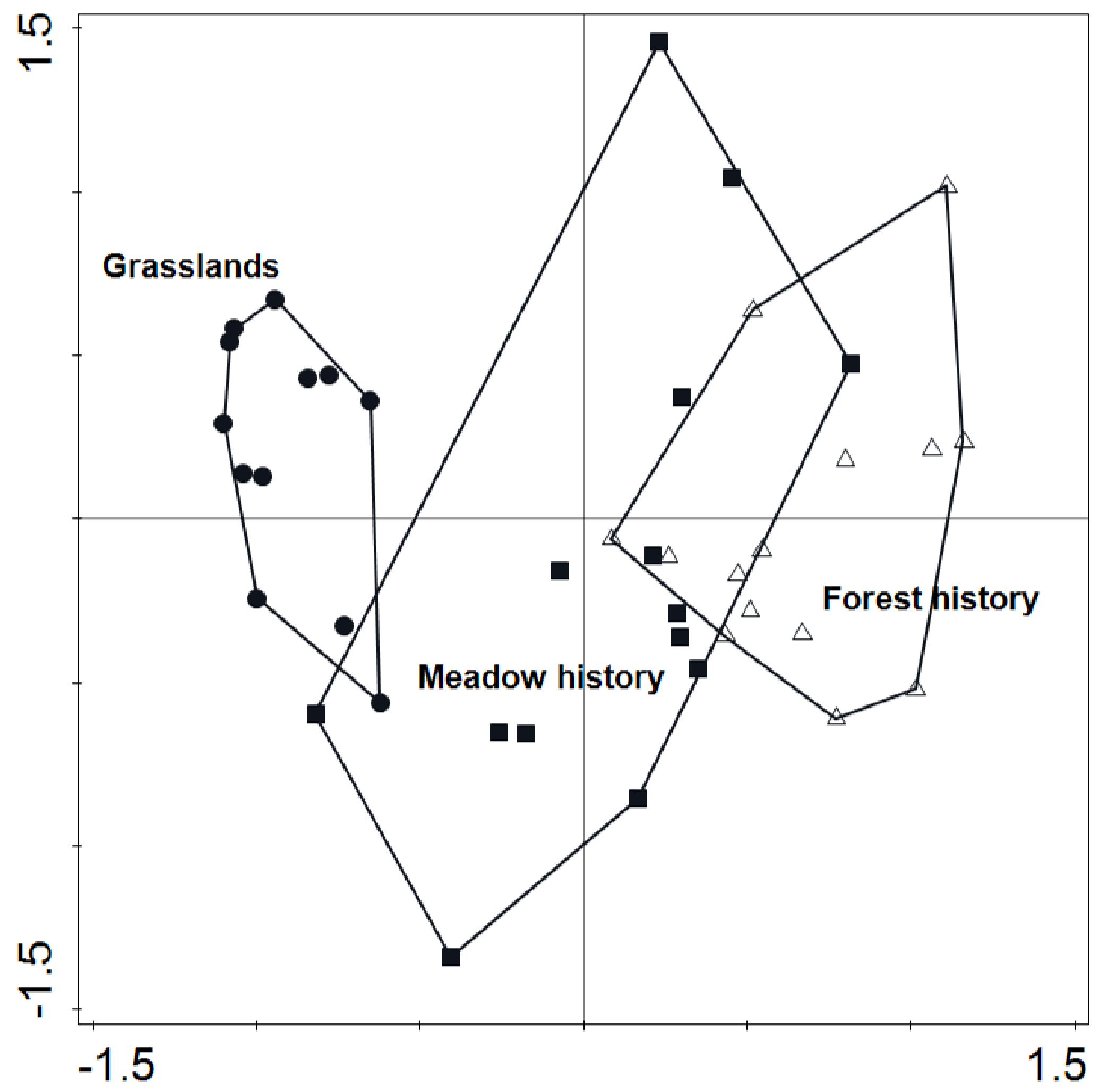


Table 1. Mean values and $\mathrm{Cl}_{95 \%}$ for habitat attributes for the three different types of study sites: forest with a history as forest, forest with a history as meadow and grassland.

\begin{tabular}{|c|c|c|c|c|c|c|}
\hline & \multicolumn{2}{|c|}{ History as forest } & \multicolumn{2}{|c|}{ History as meadow } & \multicolumn{2}{|c|}{ Grassland } \\
\hline & Mean & $\mathrm{Cl}_{95 \%}$ & Mean & $\mathrm{Cl}_{95 \%}$ & Mean & $\mathrm{Cl}_{95 \%}$ \\
\hline Size (ha) & 4.26 & $3.21-5.31$ & 3.98 & $3.26-4.70$ & 4.42 & $3.57-5.27$ \\
\hline $\begin{array}{l}\text { Area with history } \\
\text { as meadow (ha) }\end{array}$ & & & 2.09 & $1.54-2.64$ & & \\
\hline Exposed soil (\%) & 6.75 & $3.30-10.21$ & 10.64 & $6.71-14.57$ & 2.03 & $0.33-3.73$ \\
\hline Residue (\%) & 5.64 & $3.76-7.53$ & 9.32 & $5.07-13.58$ & 0.81 & $0.15-1.48$ \\
\hline Bare rock (\%) & 1.34 & $0.94-1.74$ & 1.39 & $0.82-1.95$ & 6.46 & $4.24-8.68$ \\
\hline $\begin{array}{l}\text { Number of stumps } \\
(>10 \mathrm{~cm})\end{array}$ & 0.55 & $0.40-0.71$ & 0.92 & $0.57-1.26$ & 0.13 & $0.06-0.19$ \\
\hline $\begin{array}{l}\text { Basal area } \\
\text { coniferous (m²/ha) }\end{array}$ & 22.20 & $18.88-25.51$ & 19.23 & $15.29-23.16$ & 0.10 & $0.03-0.24$ \\
\hline $\begin{array}{l}\text { Basal area } \\
\left.\text { deciduous ( } \mathrm{m}^{2} / \mathrm{ha}\right)\end{array}$ & 0.76 & $0.29-1.23$ & 1.76 & $0.29-3.22$ & 2.56 & $1.43-3.68$ \\
\hline $\begin{array}{l}\text { Basal area total } \\
\left(\mathrm{m}^{2} / \mathrm{ha}\right)\end{array}$ & 22.96 & $19.76-26.15$ & 20.98 & $17.61-24.36$ & 2.66 & $1.55-3.77$ \\
\hline
\end{tabular}


Table 1. List of traits, their data type, range of values, proportion of species for which trait values existed in the databases and source for the trait values.

\begin{tabular}{lcccc}
\hline Traits & Variable type & Values & Proportion availble (\%) & Source \\
\hline Lifeform & Categorical & $1-4$ & 99 & www.lundsbotaniska.se \\
Plant height & Continuous & $0.053-2.50$ & 97 & Kleyer et al. 2008 \\
Grazing/Moving tolerance & Categorical & $1-3$ & 92 & www.lundsbotaniska.se \\
Ellenberg light & Categorical & $1-9$ & 93 & www.lundsbotaniska.se \\
Ellenberg moisture & Categorical & $1-10$ & 85 & www.lundsbotaniska.se \\
Ellenberg pH & Categorical & $1-9$ & 65 & www.lundsbotaniska.se \\
Ellenberg nitrogen & Categorical & $1-8$ & 88 & www.lundsbotaniska.se \\
Diaspore mass & Continuous & $0.002-43.9$ & 90 & Hintze et al. 2013, Kleyer et al. 2008 \\
Terminal velocity & Continuous & $0.075-2.45$ & 83 & Hintze et al. 2013, Kleyer et al. 2008 \\
Epizoochory & Rank & $0-1$ & 65 & Hintze et al. 2013 \\
Seed Bank & Categorical & $1-4$ & 72 & www.lundsbotaniska.se \\
& & & &
\end{tabular}

square root. transforme

square root transformec square root. transforme 
Table 3. List of the SD of sitewise average of traits, and weighted traits, in forest with a meadow history and grasslands; continuous conifer forests are included for reference. P-values for the comparison of SD in grasslands and forest with meadow history

Lifeform

SD

Weighted SD

sqrt(plant height)

SD

Weighted SD

Grazing tolerance SD

Weighted SD

Ellen light

SD

Weighted SD

Ellen moisture

SD

Weighted SD

Ellen $\mathrm{pH}$

SD

D
Grassland

Meadow

history

Forest history

Grassland

Meadow

history

Forest history

Grassland

Meadow

history

Forest history

Grassland

Meadow

history

Forest history

Grassland

Meadow

history

Forest history

Grassland

Meadow

history

Forest history

Grassland

Meadow

history

Forest history

Grassland

Meadow

history

Forest history

Grassland

Meadow

history

Forest history

Grassland

Meadow

history

Forest history

Grassland
SD

$$
-\mathrm{Cl}_{95 \%}
$$$$
+\mathrm{Cl}_{95 \%}
$$

P

$$
\begin{array}{lll}
0.669 & 0.371 & 0.966 \mathrm{~ns}
\end{array}
$$

0.632

0.374

0.890

0.590

0.349

0.831

0.440

0.244

0.636 ns +

0.601

0.356

0.846

0.621

0.368

0.875

$\begin{array}{lll}0.200 & 0.111 & 0.289\end{array}$

0.211

0.125

0.298

0.216

0.128

0.304

0.175

0.097

$0.253 \mathrm{~ns}$

0.208

0.123

0.293

0.208

0.123

0.293

0.748

0.415

1.081 ns

0.657

0.389

0.926

0.631

0.373

0.888

0.625

0.347

$0.903 \mathrm{~ns}$

0.565

0.334

0.795

0.523

0.310

0.736

1.473

0.817

2.128 ns

1.758

1.040

2.475

1.730

1.024

2.436

1.058

0.587

1.529 NS +

1.732

1.025

2.439

1.718

1.017

2.420

$\begin{array}{lll}1.283 & 0.712 & 1.854\end{array}$

1.236

0.732

1.741

0.912

0.540

1.285

1.026

0.570

1.483 ns

0.960

0.568

1.351

0.611

0.362

0.860

2.097

1.164

$3.030 \mathrm{~ns}$ 


\begin{tabular}{|c|c|c|c|c|c|}
\hline & $\begin{array}{l}\text { Meadow } \\
\text { history }\end{array}$ & 2.040 & 1.207 & 2.873 & \\
\hline & Forest history & 1.919 & 1.136 & 2.703 & \\
\hline \multirow[t]{4}{*}{ Weighted SD } & Grassland & 1.860 & 1.033 & 2.688 & ns \\
\hline & Meadow & & & & \\
\hline & history & 1.623 & 0.961 & 2.286 & \\
\hline & Forest history & 1.301 & 0.770 & 1.832 & \\
\hline \multicolumn{6}{|l|}{ Ellen $\mathrm{N}$} \\
\hline \multirow[t]{4}{*}{ SD } & Grassland & 2.080 & 1.154 & 3.006 & ns \\
\hline & Meadow & & & & \\
\hline & history & 1.958 & 1.159 & 2.758 & \\
\hline & Forest history & 1.835 & 1.086 & 2.584 & \\
\hline \multirow[t]{4}{*}{ Weighted SD } & Grassland & 1.877 & 1.042 & 2.712 & ns \\
\hline & Meadow & & & & \\
\hline & history & 1.598 & 0.946 & 2.251 & \\
\hline & Forest history & 1.445 & 0.855 & 2.034 & \\
\hline \multicolumn{6}{|l|}{ Diaspore } \\
\hline \multirow[t]{4}{*}{ SD } & Grassland & 0.972 & 0.539 & 1.405 & ns \\
\hline & Meadow & & & & \\
\hline & history & 1.116 & 0.660 & 1.571 & \\
\hline & Forest history & 1.224 & 0.724 & 1.723 & \\
\hline \multirow[t]{3}{*}{ Weighted SD } & $\begin{array}{l}\text { Grassland } \\
\text { Meadow }\end{array}$ & 0.935 & 0.519 & 1.351 & ns \\
\hline & history & 0.975 & 0.577 & 1.372 & \\
\hline & Forest history & 0.924 & 0.547 & 1.301 & \\
\hline \multicolumn{6}{|l|}{$\begin{array}{l}\text { sqrt(terminal } \\
\text { velocity) }\end{array}$} \\
\hline \multirow[t]{4}{*}{ SD } & Grassland & 0.413 & 0.229 & 0.597 & ns \\
\hline & Meadow & & & & \\
\hline & history & 0.463 & 0.274 & 0.652 & \\
\hline & Forest history & 0.426 & 0.252 & 0.600 & \\
\hline \multirow[t]{4}{*}{ Weighted SD } & Grassland & 0.373 & 0.207 & 0.539 & ns \\
\hline & Meadow & & & & \\
\hline & history & 0.435 & 0.257 & 0.613 & \\
\hline & Forest history & 0.354 & 0.209 & 0.498 & \\
\hline \multicolumn{6}{|l|}{ epizoo } \\
\hline \multirow[t]{4}{*}{ SD } & Grassland & 0.295 & 0.163 & 0.426 & ns \\
\hline & Meadow & & & & \\
\hline & history & 0.318 & 0.188 & 0.448 & \\
\hline & Forest history & 0.330 & 0.195 & 0.464 & \\
\hline \multirow[t]{4}{*}{ Weighted SD } & Grassland & 0.290 & 0.161 & 0.419 & ns \\
\hline & Meadow & & & & \\
\hline & history & 0.301 & 0.178 & 0.424 & \\
\hline & Forest history & 0.277 & 0.164 & 0.390 & \\
\hline \multicolumn{6}{|l|}{ Seedbank } \\
\hline \multirow[t]{4}{*}{ SD } & Grassland & 1.052 & 0.584 & 1.520 & ns \\
\hline & Meadow & & & & \\
\hline & history & 1.069 & 0.632 & 1.505 & \\
\hline & Forest history & 1.073 & 0.635 & 1.511 & \\
\hline \multirow[t]{4}{*}{ Weighted SD } & Grassland & 0.941 & 0.522 & 1.359 & ns \\
\hline & Meadow & & & & \\
\hline & history & 0.926 & 0.548 & 1.304 & \\
\hline & Forest history & 0.826 & 0.489 & 1.164 & \\
\hline
\end{tabular}


Appendix 1: Total plant species frequencies in three different study sites; grasslands, forests with a history as forest and forests with a history as meadow. Species classified as indicators for grasslands are marked with an " $x$ " in the column to the right.

\begin{tabular}{|c|c|c|c|c|}
\hline \multirow[b]{2}{*}{ Species } & \multicolumn{3}{|c|}{ Plant frequency } & \multirow[b]{2}{*}{ Indicator species } \\
\hline & $\begin{array}{c}\begin{array}{c}\text { Grassland } \\
\text { (max } \\
1200)\end{array} \\
\end{array}$ & $\begin{array}{l}\text { History as forest } \\
(\max 1400)\end{array}$ & $\begin{array}{l}\text { History as meadow } \\
(\max 1400)\end{array}$ & \\
\hline Achillea millefolium & 788 & 2 & 4 & \\
\hline Achillea ptarmica & 0 & 0 & 2 & \\
\hline Actaea spicata & 0 & 0 & 1 & \\
\hline Aegopodium podagraria & 63 & 2 & 23 & \\
\hline Agrimonia eupatoria & 4 & 0 & 0 & $x$ \\
\hline Agrostis capillaris & 737 & 29 & 67 & \\
\hline Ajuga pyramidalis & 53 & 9 & 24 & $x$ \\
\hline Alchemilla vulgaris & 620 & 0 & 8 & $x$ \\
\hline Andromeda polifolia & 0 & 0 & 1 & \\
\hline Anemone hepatica & 34 & 62 & 170 & \\
\hline Anemone nemorosa & 1 & 4 & 23 & \\
\hline Anthoxanthum odoratum & 474 & 45 & 22 & $x$ \\
\hline Anthriscus sylvestris & 295 & 7 & 95 & \\
\hline Aquilegia vulgaris & 0 & 0 & 3 & \\
\hline Arctium minus & 0 & 0 & 4 & \\
\hline Argentina anserina & 6 & 1 & 0 & $x$ \\
\hline Arnica montana & 1 & 0 & 0 & $\mathrm{x}$ \\
\hline Arrhenatherum elatius & 1 & 0 & 4 & \\
\hline Artemisia vulgaris & 5 & 1 & 0 & \\
\hline Astragalus glycyphyllos & 0 & 0 & 3 & \\
\hline Bistorta vivipara & 2 & 0 & 0 & $\mathrm{x}$ \\
\hline Briza media & 101 & 0 & 0 & $\mathrm{x}$ \\
\hline Calamagrostis arundinacea & 34 & 418 & 408 & \\
\hline Calluna vulgaris & 21 & 160 & 81 & \\
\hline Campanula persicifolia & 85 & 80 & 131 & $x$ \\
\hline Campanula rotundifolia & 376 & 3 & 10 & $\mathrm{x}$ \\
\hline Chamerion angustifolium & 6 & 2 & 7 & \\
\hline Chelidonium majus & 0 & 0 & 1 & \\
\hline Chrysosplenium alternifolium & 5 & 3 & 4 & \\
\hline Cirsium acaule & 1 & 0 & 0 & $\mathrm{x}$ \\
\hline Cirsium arvense & 3 & 0 & 11 & \\
\hline Cirsium palustre & 95 & 1 & 10 & \\
\hline Cirsium vulgare & 13 & 0 & 2 & \\
\hline Clinopodium vulgare & 12 & 3 & 9 & \\
\hline Convallaria majalis & 20 & 27 & 48 & \\
\hline Crepis praemorsa & 1 & 0 & 0 & $x$ \\
\hline Cynosurus cristatus & 137 & 0 & 0 & $x$ \\
\hline Dactyils glomerata & 212 & 17 & 35 & \\
\hline Dactylorhiza maculata & 0 & 0 & 4 & $\mathrm{x}$ \\
\hline Daphne mezereum & 0 & 2 & 13 & \\
\hline Deschampsia cespitosa & 142 & 16 & 116 & \\
\hline Deschampsia flexuosa & 710 & 1048 & 759 & \\
\hline
\end{tabular}




\begin{tabular}{|c|c|c|c|c|}
\hline Dryopteris filix-mas & 56 & 63 & 175 & \\
\hline Elytrigia repens & 4 & 0 & 3 & \\
\hline Empetrum nigrum & 0 & 1 & 3 & \\
\hline Epilobium adenocaulon & 13 & 2 & 34 & \\
\hline Equisetum arvense & 2 & 6 & 28 & \\
\hline Equisetum hyemale & 0 & 12 & 0 & \\
\hline Equisetum palustre & 1 & 0 & 3 & \\
\hline Equisetum pratense & 20 & 1 & 90 & \\
\hline Equisetum silvaticum & 33 & 65 & 130 & \\
\hline Euphrasia stricta var. stricta & 14 & 0 & 0 & $\mathrm{x}$ \\
\hline Festuca ovina & 348 & 103 & 53 & $x$ \\
\hline Filipendula ulmaria & 104 & 17 & 83 & \\
\hline Filipendula vulgaris & 5 & 0 & 1 & $x$ \\
\hline Fragaria vesca & 344 & 103 & 142 & \\
\hline Galeopsis tetrahit & 7 & 0 & 14 & \\
\hline Gentianella campestris & 2 & 0 & 0 & $x$ \\
\hline Geranium robertianum & 2 & 0 & 34 & \\
\hline Geranium sylvaticum & 305 & 25 & 43 & \\
\hline Geum rivale & 183 & 5 & 86 & \\
\hline Glechoma hederacea & 40 & 0 & 7 & \\
\hline Gnaphalium sylvaticum & 13 & 0 & 2 & \\
\hline Goodyera repens & 0 & 28 & 0 & \\
\hline Gymnocarpium dryopteris & 4 & 32 & 9 & \\
\hline Helianthemum nummularium & 21 & 0 & 0 & $x$ \\
\hline Hieracium sect. Hieracium & 310 & 90 & 151 & \\
\hline Hylotelephium telephium & 2 & 1 & 2 & \\
\hline Hypericum maculatum & 688 & 61 & 143 & \\
\hline Hypericum perforatum & 2 & 0 & 1 & $x$ \\
\hline Inula salicina & 1 & 0 & 0 & \\
\hline Juncus articulatus & 5 & 0 & 0 & $x$ \\
\hline Juncus bufonius & 0 & 0 & 2 & \\
\hline Juncus conglomeratus & 62 & 0 & 3 & \\
\hline Juncus effusus & 57 & 3 & 36 & \\
\hline Knautia arvensis & 379 & 19 & 33 & \\
\hline Lactuca muralis & 16 & 110 & 289 & \\
\hline Lactuca serriola & 0 & 0 & 1 & \\
\hline Lathyrus linifolius & 525 & 260 & 303 & $x$ \\
\hline Lathyrus pratensis & 349 & 6 & 21 & \\
\hline Leontodon autumnalis & 124 & 0 & 0 & $x$ \\
\hline Leucanthemum vulgare & 49 & 0 & 5 & $x$ \\
\hline Linaea borealis & 0 & 123 & 9 & \\
\hline Lolium perenne & 6 & 0 & 0 & \\
\hline Lotus corniculatus & 194 & 4 & 2 & $\mathrm{x}$ \\
\hline Luzula pilosa & 118 & 881 & 689 & \\
\hline Lycopodium annotinum & 0 & 16 & 18 & \\
\hline Lycopodium clavatum & 0 & 0 & 1 & \\
\hline Lycopus europaeus & 0 & 0 & 1 & \\
\hline Lysimachia vulgaris & 0 & 22 & 24 & \\
\hline Maianthemum bifolium & 12 & 205 & 156 & \\
\hline
\end{tabular}




\begin{tabular}{|c|c|c|c|c|}
\hline Matricaria suaveolens & 3 & 0 & 0 & \\
\hline Melampyrum pratense/sylvaticum & 29 & 414 & 379 & \\
\hline Mentha arvensis & 6 & 2 & 1 & \\
\hline Menyanthes trifoliata & 0 & 0 & 1 & \\
\hline Monotropa hypopitys & 0 & 5 & 0 & \\
\hline Myosotis scorpioides & 5 & 0 & 1 & $x$ \\
\hline Nardus stricta & 40 & 0 & 0 & $x$ \\
\hline Origanum vulgare & 2 & 0 & 2 & \\
\hline Orthilia secunda & 4 & 49 & 34 & \\
\hline Oxalis acetosella & 25 & 585 & 452 & \\
\hline Paris quadrifolia & 0 & 0 & 2 & \\
\hline Persicaria hydropiper & 2 & 0 & 0 & \\
\hline Persicaria maculosa & 1 & 0 & 0 & \\
\hline Peucedanum palustre & 0 & 0 & 1 & \\
\hline Phegopteris connectilis & 2 & 27 & 43 & \\
\hline Phleum pratense & 120 & 1 & 10 & \\
\hline Phragmites australis & 1 & 0 & 9 & \\
\hline Pilosella lactucella & 4 & 0 & 6 & $x$ \\
\hline Pilosella officinarum & 441 & 2 & 7 & $x$ \\
\hline Pimpinella saxifraga & 306 & 4 & 10 & $x$ \\
\hline Plantago lanceolata & 725 & 0 & 2 & $x$ \\
\hline Plantago major & 129 & 0 & 0 & \\
\hline Plantago media & 7 & 0 & 0 & $x$ \\
\hline Poa nemoralis & 0 & 0 & 11 & \\
\hline Polygala vulgaris & 71 & 0 & 0 & $x$ \\
\hline Polygonatum odoratum & 1 & 0 & 0 & \\
\hline Polygonum aviculare & 20 & 0 & 0 & $x$ \\
\hline Polypodium vulgare & 6 & 100 & 75 & \\
\hline Potentilla argentea & 4 & 0 & 0 & $x$ \\
\hline Potentilla erecta & 569 & 129 & 185 & \\
\hline Potentilla norvegica & 1 & 0 & 0 & \\
\hline Potentilla palustris & 11 & 5 & 3 & \\
\hline Primula veris & 61 & 3 & 10 & $x$ \\
\hline Prunella vulgaris & 159 & 0 & 3 & \\
\hline Pteridium aquilinum & 290 & 365 & 178 & \\
\hline Pyrola rotundifolia & 1 & 0 & 3 & \\
\hline Ranunculus acris & 785 & 9 & 71 & $x$ \\
\hline Ranunculus flammula & 1 & 0 & 1 & \\
\hline Ranunculus repens & 101 & 8 & 131 & \\
\hline Rhinanthus minor & 33 & 0 & 0 & $x$ \\
\hline Rhododendron tomentosum & 0 & 0 & 27 & \\
\hline Rubus chamaemorus & 0 & 0 & 5 & \\
\hline Rubus idaeus & 112 & 152 & 238 & \\
\hline Rubus saxatilis & 37 & 33 & 138 & \\
\hline Rumex acetosa & 578 & 2 & 18 & \\
\hline Rumex acetosella & 28 & 2 & 0 & $x$ \\
\hline Satureja acinos & 0 & 0 & 1 & $x$ \\
\hline Saxifraga granulata & 12 & 0 & 0 & $x$ \\
\hline Scorzonera humilis & 38 & 2 & 18 & $\mathrm{x}$ \\
\hline
\end{tabular}




\begin{tabular}{|c|c|c|c|c|}
\hline Scrophularia nodosa & 0 & 0 & 3 & \\
\hline Scutellaria galericulata & 0 & 2 & 0 & \\
\hline Senecio sylvaticus & 1 & 0 & 7 & \\
\hline Senicio viscosus & 0 & 0 & 1 & \\
\hline Solanum dulcamara & 0 & 0 & 1 & \\
\hline Solidago canadensis & 0 & 0 & 1 & \\
\hline Solidago virgauera & 8 & 44 & 82 & \\
\hline Stachys sylvatica & 0 & 0 & 13 & \\
\hline Stellaria media & 251 & 19 & 39 & \\
\hline Succisa pratensis & 44 & 31 & 41 & $x$ \\
\hline Taraxacum sect. Ruderalia & 370 & 7 & 47 & \\
\hline Trientalis europaea & 6 & 201 & 110 & \\
\hline Trifolium medium & 9 & 3 & 8 & \\
\hline Trifolium pratense & 761 & 8 & 36 & $x$ \\
\hline Trifolium repens & 504 & 0 & 1 & $x$ \\
\hline Trollius europaeus & 22 & 1 & 8 & $x$ \\
\hline Tussilago farfara & 5 & 0 & 24 & \\
\hline Urtica dioica & 34 & 4 & 71 & \\
\hline Vaccinium myrtillus & 206 & 1027 & 645 & \\
\hline Vaccinium oliginosum & 1 & 0 & 25 & \\
\hline Vaccinium oxycoccos & 0 & 0 & 7 & \\
\hline Vaccinium vitis-idaea & 120 & 628 & 376 & \\
\hline Veronica chamaedrys & 686 & 74 & 227 & $x$ \\
\hline Veronica officinalis & 215 & 143 & 164 & $x$ \\
\hline Vicia cracca & 429 & 7 & 29 & \\
\hline Vicia sepium & 145 & 31 & 44 & \\
\hline Vicia sylvatica & 0 & 5 & 9 & \\
\hline Viola riviana & 503 & 303 & 391 & \\
\hline Total frequency & 18569 & 8643 & 9419 & \\
\hline Total species richness & 133 & 91 & 134 & \\
\hline Total richness indicator species & 46 & 19 & 27 & 48 \\
\hline
\end{tabular}

